УДК 546.881'33’47’48

\author{
Т.И. Красненко ${ }^{1 *}$, Т.П. Сирина ${ }^{2}$, В.В. Викторов ${ }^{2}$, М.В. Ротермель ${ }^{1}$, Г.В. Соловьев ${ }^{2}$ \\ ${ }^{1}$ Институт химии твердого тела УрО РАН, Россия, г. Екатеринбург \\ ${ }^{2}$ Челябинский государственный педагогический университет, Россия, г. Челябинск \\ "E-mail: krasnenko@ihim.uran.ru
}
Разработка физико-химических и технологических основ рационального использования ванадий-никель-железо-кальцийсодержащих отходов теплоэлектростанций

\begin{abstract}
Комплексом исследований физико-химических свойств отходов теплоэлектростанций, сжигающих мазут, фазовых соотношений в модельных системах $\mathrm{V}_{2} \mathrm{O}_{5}-\mathrm{NiO}(\mathrm{MgO})-\mathrm{CaO}-\mathrm{Na}_{2} \mathrm{O}$ и растворимостей основных фаз, образующихся при термообработке, показана возможность их переработки по единой технологической схеме с получением товарных ванадий-, никель- и кальцийсодержащих продуктов.

Ключевые слова: ТЭС, шлам химической водоочистки, ванадий-никель-железо-кальцийсодержащие отходы теплоэлектростанций, аттестация шламов, десульфурация отходов ТЭС.
\end{abstract}

T.I. Krasnenko, T.P. Sirina, V.V. Viktorov, M.V. Rotermel, G.V. Solovyov

Development of physico-chemical and technological foundations of rational use of vanadium-nickel-iron-calcium containing power plants wastes

Complex investigations of physical and chemical properties of wastes of thermal power plants burning fuel-oil were carried out. The phase relations in model systems $\mathrm{V}_{2} \mathrm{O}_{5}-\mathrm{NiO}(\mathrm{MgO})-\mathrm{CaO}-\mathrm{Na}_{2} \mathrm{O}$ and solubility of the major phases formed at heat treatment were studied. The possibility of obtaining of trade vanadium, nickel and calcium-containing products is shown on a single technological scheme.

Key words: thermal power plants, chemical water treatment sludge, vanadium-nickel-iron-calcium containing thermal power plants wastes, sludge certification, thermal power plant wastes desulphurization.

Т.И. Красненко, Т.П. Сирина, В.В. Викторов, М.В. Ротермель, Г.В. Соловьев

Жылу электрстанциясының ванадий-никель-темірлі қалдықтарын рационалды пайдаланудың физика-химиялық және технологиялық негіздерін жасау

Мазут жағатын жылу электр станциялары қалдықтарын комплексті физика-химиялық әдістер арқылы зерттеп және модельді $\mathrm{V}_{2} \mathrm{O}_{5}-\mathrm{NiO}(\mathrm{MgO})-\mathrm{CaO}-\mathrm{Na}_{2} \mathrm{O}$ жүйесі негізінде ванадий-никель-кальций заттарын алу технологиясы көрсетілген.

Tүйін сөздер: жылу электрстанциясы, химиялық су тазарту шламы, ванадий-никель-теміршікальцийлі қалдықтар, шламды аттестациялау, қалдықтарды десульфурациялау.

Во многих регионах мира значительную роль в производстве электроэнергии играют тепловые электростанции (ТЭС), сжигающие мазут.

Высокосернистые мазуты содержат металлорганические соединения ванадия, железа и др. элементов. При сжигании мазута в системе котлоагрегатов эти элементы концентрируются в золах-композициях, содержание ванадия, никеля и др. компонентов в которых зависит от температуры отходящих газов. При водных обмывках поверхностей нагрева и нейтрализации, образующихся при этом кислых обмывочных вод ванадий, никель и др. элементы переходят в шламы. Из-за отсутствия на ТЭС золоулавливающих устройств большая часть ценных металлов теряется с «золой уноса» и загрязняет биосферу токсичными соединениями ванадия, никеля, серы и др. Соотношение видов ванадийсодержащих композиций по отношению к ванадию, содержащемуся в сожженном мазуте, приведено на рисунке 1 [1]. Отметим, что условно проведено разделение на «богатые» (выше $10 \% \mathrm{~V}_{2} \mathrm{O}_{5}$ ) и «бедные» виды зол и шламов. В таблице 1 по данным [1] приведен среднестатистический состав отходов ТЭС с учетом результатов 
исследований, определивших количество $\mathrm{V}_{2} \mathrm{O}_{5}$, содержащейся в каждом виде отходов, а также рассчитанный авторами состав смеси, которая может поступить на переработку при условии сбора всех ванадийсодержащих видов отходов ТЭС. Из этих данных следует, что, как исходное сырье для извлечения ценных компонентов, так и отходы ТЭС имеют целый ряд существенных отличий от традиционного в нашей стране сырья ванадиевых конвертерных шлаков:

- переменное содержание $\mathrm{V}_{2} \mathrm{O}_{5}(1,5-40 \%)$ и фазовый состав в пяти основных видах композиций;

- высокое содержание серы от 3 до 15 \%;
- высокое содержание углерода (зола уноса до $90 \%$ );

- наличие второго ценного компонентаникеля (0,5-8 \% мас.);

- присутствие ванадия в 3, 4 и 5-ти валентном состоянии и частично в виде водорастворимых соединений;

- отсутствие высокого содержания марганца, играющего существенную роль при формировании растворимых ванадатов на стадии термообработки;

- присутствие в ряде видов сырья канцерогенного соединения - бенз(а)пирена (от $0,5 * 10^{-6}$ до $\left.0,7 * 10^{-4} \%\right)$.

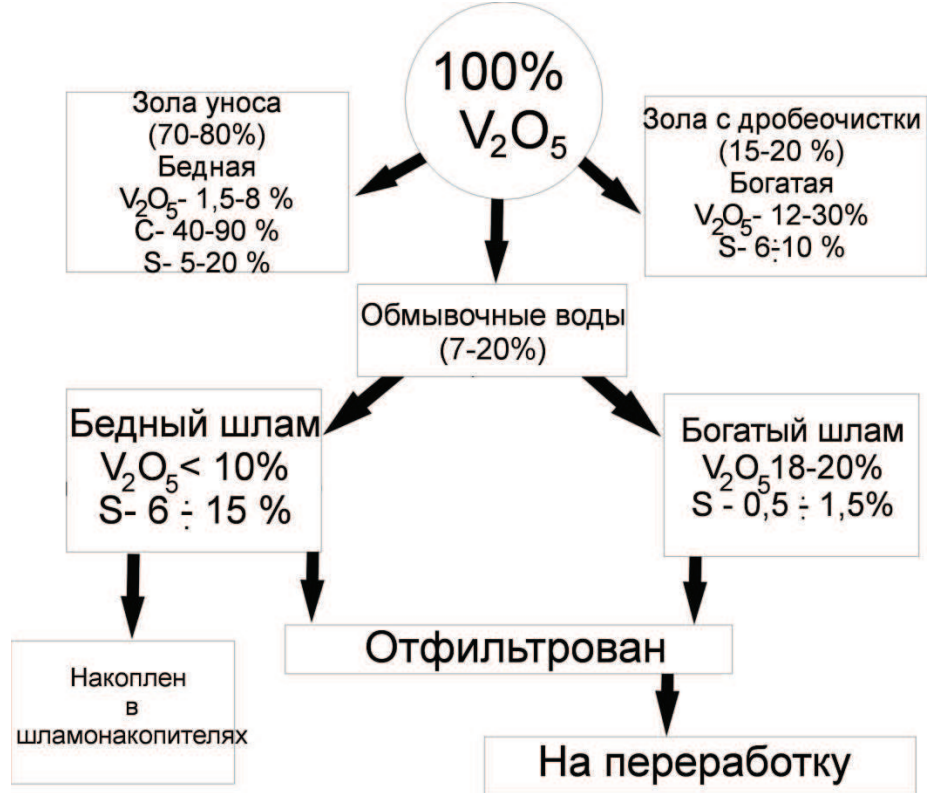

Рисунок 1 - Ванадий содержащие композиции, образующиеся в различных зонах котлоагрегата. $\mathrm{B}$ скобках - проценты от общего количества $\mathrm{V}_{2} \mathrm{O}_{5}$, поступившего с мазутом на сжигание [1]

Таблица 1 - Среднестатистический состав ванадийсодержащих зол и шламов ТЭС [1].

\begin{tabular}{|c|c|c|c|c|c|c|c|c|c|c|}
\hline \multirow{2}{*}{$\begin{array}{c}\text { Виды зол и } \\
\text { шламов }\end{array}$} & \multirow{2}{*}{$\begin{array}{c}\text { Количеств } \\
\text { о } \mathrm{V}_{2} \mathrm{O}_{5} \text { в } \\
\text { каждом } \\
\text { виде, } \\
\text { \% отн. } \\
\end{array}$} & & \multicolumn{8}{|c|}{ Состав на сухую массу, \% мас. } \\
\hline & & $\mathrm{V}_{2} \mathrm{O}_{5}$ & $\mathrm{NiO}$ & $\mathrm{Fe}_{2} \mathrm{O}_{3}$ & $\mathrm{CaO}$ & $\mathrm{MgO}$ & $\mathrm{SiO}_{2}$ & $\mathrm{Na}_{2} \mathrm{O}$ & $\mathrm{C}$ & $\mathrm{S}$ \\
\hline $\begin{array}{l}\text { Зола уноса } \\
\text { (бедная) }\end{array}$ & 70 & 5,24 & 3,45 & 6,52 & 1,46 & 0,80 & 6,24 & 0,98 & 68,7 & 5,10 \\
\hline Богатая зола & 15 & 27,4 & 7,00 & 2,04 & 3,06 & 1,08 & 8,02 & 3,20 & 3,71 & 6,97 \\
\hline Богатый шлам & 7 & 25,1 & 1,30 & 30,7 & 6,07 & 0,4 & 4,20 & 0,69 & 6,67 & 5,04 \\
\hline Бедный & 7 & 6,72 & 1,48 & 50,1 & 15,0 & 5,5 & 4,66 & Следы & 4,54 & 6,73 \\
\hline Зола с газоходов & 1 & 4,58 & 1,82 & 19,7 & 1,58 & - & 12,9 & 1,12 & 16,1 & 13,3 \\
\hline $\begin{array}{l}\text { Смесь всех видов } \\
\text { согласно } \\
\text { количества } \mathrm{V}_{2} \mathrm{O}_{5} \text { в } \\
\text { каждом }\end{array}$ & 100 & 6,47 & 3,38 & 10,6 & 2,51 & - & 6,25 & 0,99 & 60,2 & 5,65 \\
\hline
\end{tabular}


Эти особенности обусловили необходимость разработки физико-химических и технологических основ для создания процессов комплексной переработки зол и шламов ТЭС.

Ванадий и никель являются ценными стратегически важными металлами, а их количество в ежегодно сжигаемых мазутах только Тюменского и Волжско-Уральского региона превышает 10000 т и 2000 т соответственно [1].

В некоторых странах отходы ТЭС активно вовлекаются в производственную сферу. В Японии к концу 80-х годов около $20 \%$ потребности ванадия покрывалось за счет переработки отходов ТЭС. В Канаде, США и Венесуэле ванадий, а также никель получают не только из зольных остатков ТЭС, но и из нефти и битума. В России переработка ванадий-никель-железосодержащих отходов электростанций до сих пор не освоена.

Существует и экологический аспект необходимости переработки отходов теплостанций.

Наиболее токсичными являются соединения ванадия, никеля, серы и бенз(а)пирен. На основании токсикологической оценки отходов, проведенной ВНИИ техники безопасности, приведенных в [1], все виды отходов ТЭС характеризуются как «вещества умеренно опасные» (III класс опасности).

Перед подачей питательной воды в котлоагрегаты природная вода проходит ряд стадий обработки. Для снижения ее жесткости существует стадия химической обработки гидроксидом кальция и сульфатом железа (II). При этом образуется осадок - шлам химической водоочистки (XBO), который направляют в шламонакопители. Площадь этих сооружений колеблется от 1000 до 3000 га. Исследование химического и фазового состава сухих шламов XВО показали их идентичность на различных ТЭС. Основной их фазой является карбонат кальция (кальцит).

Цель настоящей работы - комплексная переработка двух отходов ТЭС, ванадий - и никельсодержащих отложений (зол и шламов) и кальцийсодержащих шламов ХВО с получением технической пятиокиси ванадия для выплавки феррованадия, композита, содержащего никель, железо и гипс и являющегося комплексной шихтой для выплавки ферроникеля, обожженной извести, широко используемой в металлургии, а также сокращение токсичных выбросов и площадей земель, используемых под шламонакопители.

Повышение качества окружающей среды в промышленной зоне ТЭС предполагает изъятие токсичных канцерогенных соединений как из накопленных, так и из текущих поступлений, нахождение путей их детоксикации и/ или их извлечение для прагматических целей. Поскольку все соединения ванадия, никеля и серы токсичны, детоксикация их невозможна, следовательно, необходим поиск путей извлечения этих соединений для последующего использования.

Элементный и фазовый состав ванадийникель-железо-кальций содержащих отходов теплоэлектростанций

Усредненный химический состав энергетических отложений в пересчете на оксиды характеризуется наличием $\mathrm{V}_{2} \mathrm{O}_{5}-1,5-50 \%$; $\mathrm{Na}_{2} \mathrm{O}-1-9 \%$; $\mathrm{CaO}-0,8-30 \%, \quad \mathrm{MgO}-2,5-10 \%$; $\mathrm{NiO}-1-10,2 \% ; \mathrm{Fe}_{2} \mathrm{O}_{3}-4,0-48 \% ; \mathrm{SiO}_{2}-10-20 \%$. В шламах ХВО содержится до $52 \% \mathrm{CaO}, 2,0-$ $4,5 \% \mathrm{MgO}$, до $4 \% \mathrm{SiO}_{2}$, до $14,4 \%$ углерода, 0,02-0,06\% $\%$, 1,4-11,7\% $\mathrm{Fe}_{2} \mathrm{O}_{3}$, потери при прокаливании при $400-600{ }^{\circ} \mathrm{C}$ составляют $\approx 40 \%$. Ванадий в отложениях входит в состав ванадатов натрия, магния, кальция и никеля, оксидных натрий-ванадиевых бронз, шпинелей, силикатных фаз, пятиокиси ванадия. Никель находится в составе шпинели, образует ванадаты и ферриты. Основными соединениями, входящими в состав шлама XВО после прокаливания при $1000{ }^{\circ} \mathrm{C}$ в течение одного часа, являются $\mathrm{CaO}$ (95-97\%) и феррит кальция $\mathrm{Ca}_{2} \mathrm{Fe}_{2} \mathrm{O}_{5}$ (5-3\%) [2]. Сера присутствует в водорастворимых кристаллогидратах сульфатов никеля, железа, натрия, магния, сульфата ванадила и малорастворимого в воде кристаллогидрата сульфата кальция.

Для десульфурации ванадийсодержащих зол и шламов разработаны приемы их обработки растворами карбоната натрия.

За счет обменных реакций карбоната натрия с сульфатами ванадила, железа, магния и кальция образуется осадок смеси карбонатов этих элементов, а сера в виде сульфата натрия переходит в раствор:

$\begin{aligned} & \left(\mathrm{Fe}, \mathrm{VO}_{2}{ }^{2+}, \mathrm{Ni}, \mathrm{Mg}, \mathrm{Ca}\right) \mathrm{SO}_{4}+\mathrm{Na}_{2} \mathrm{CO}_{3}= \\ = & \left(\mathrm{Fe}, \mathrm{VO}_{2}{ }^{2+}, \mathrm{Ni}, \mathrm{Mg}, \mathrm{Ca}\right) \mathrm{CO}_{3} \downarrow+\mathrm{Na}_{2} \mathrm{SO}_{4}\end{aligned}$

Утилизация углерода из отходов ТЭС может быть осуществлена его выжиганием. Эксперименты, проведенные в лабораторных условиях, показали, что этот процесс необходимо проводить в интервале температур 600$850{ }^{\circ} \mathrm{C}$. При сгорании углерода на стадии обжига отходов ТЭС полностью уничтожается бенз(а)пирен [1]. 
Исходя из реального фазового состава, непосредственная обработка ванадийсодержащих отходов в воде и кислых растворах может привести лишь к частичному извлечению ванадия в раствор. Цель различных технологических приемов переработки сырья состоит в формировании ванадиевых соединений, пригодных для такого гидрометаллургического воздействия, в результате которого возможно более полное селективное извлечение в раствор ванадия и последующее его осаждение. Требованиям селективности удовлетворяют оксидные соединения ванадия, в которых ванадийкислородный анион, наименее прочно связан с катионной подсистемой. Целевые соединения в данном случае должны обладать гетеродесмическими структурами с доминирующими ковалентной ванадий-кислородной и ионной металл-кислородной связями. К таким соединениям принадлежат, в первую очередь, сложные соединения пятивалентного ванадия ванадаты натрия и двухвалентных металлов никеля, магния, кальция. Подготовка к последующему гидрометаллургическому извлечению ванадия осуществляется в ходе обжига ванадийсодержащего сырья с добавками соединений натрия или кальция путем формирования соответственно водо- или кислоторастворимых ванадатов натрия или кальция. При разработке оптимальных технологических режимов извлечения ванадия необходимо опираться на знание диаграмм фазовых равновесий, моделирующих ванадийсодержащее сырье и композиции, являющиеся итогом его пирометаллургического передела. Такими системами являются $\mathrm{V}_{2} \mathrm{O}_{5}-\mathrm{Na}_{2} \mathrm{O}-\mathrm{CaO}-\mathrm{MO}$ $(\mathrm{M}=\mathrm{Mg}, \mathrm{Ni})$. Для построения фазовых диаграмм многокомпонентных систем использованы данные $о$ трехкомпонентных системах, опубликованные в литературе $[4,5]$, а также полученные в настоящей работе. Наряду с этим учтены возможности двойного катионного замещения кальция не только на ионы двухвалентных металлов, но и на ионы натрия.

Диаграмма фазовых равновесий, моделирующих ванадийсодержащее сырье и композиции, являющиеся итогом его пирометаллургиического передела в.системе $\mathrm{V}_{2} \mathrm{O}_{5}-\mathrm{NaVO}_{3}-$ $\mathrm{Ca}\left(\mathrm{VO}_{3}\right)_{2}-\mathrm{Ni}_{3}\left(\mathrm{VO}_{4}\right)_{2}$ приведена на рисунке 2 .

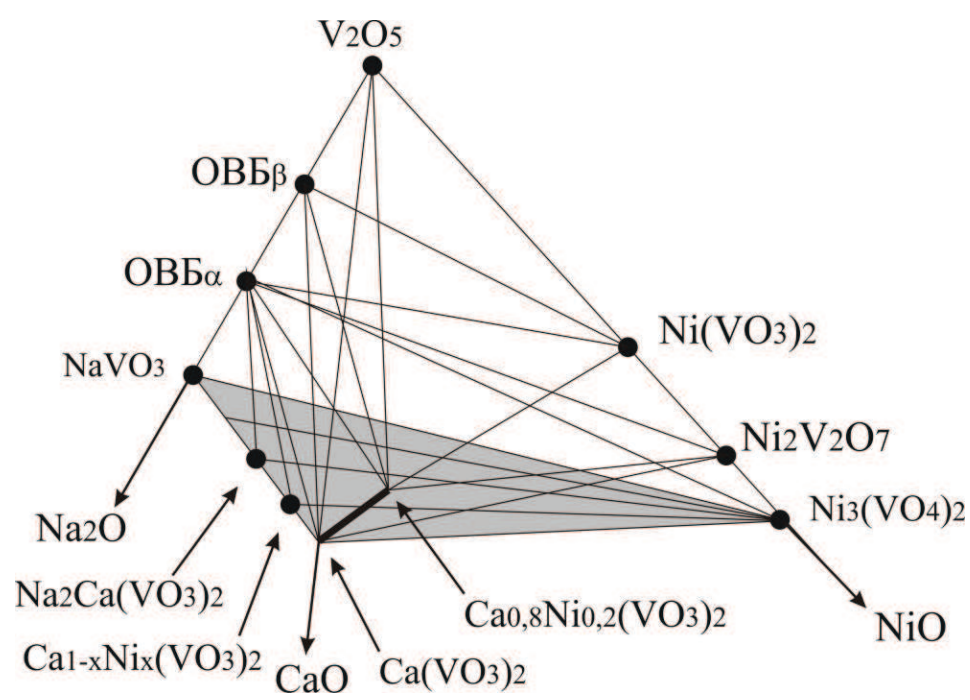

Рисунок 2 - Фазовые равновесия в системе $\mathrm{V}_{2} \mathrm{O}_{5}-\mathrm{NaVO}_{3}-\mathrm{Ca}\left(\mathrm{VO}_{3}\right)_{2}-\mathrm{Ni}_{3}\left(\mathrm{VO}_{4}\right)_{2}$

Анализ фазового состава исследованных образцов свидетельствует об отсутствии в рассматриваемой системе, как тройных ванадатов, так и одновременного замещения кальция в $\mathrm{Ca}\left(\mathrm{VO}_{3}\right)_{2}$ на натрий и никель, несмотря на существование на основе метаванадата кальция твердых растворов как с $\mathrm{NaVO}_{3}$, так и с $\mathrm{Ni}\left(\mathrm{VO}_{3}\right)_{2}$. Важно отметить, что все ванадаты никеля в состоянии равновесия сосуществуют с оксидными ванадиевыми бронзами [1].
Информация о фазовом составе многокомпонентных систем, включающих сложные оксиды ванадия, позволяет определить количество и вид добавок для получения композиций, растворение которых ведет к максимальному извлечению ванадия в растворы. Образующиеся оксидные ванадиевые бронзы натрия в системе $\mathrm{V}_{2} \mathrm{O}_{5}-\mathrm{Na}_{2} \mathrm{O}-\mathrm{CaO}-\mathrm{NiO}$ находятся в термодинамическом равновесии со всеми ванадатами никеля (мета-, пиро- и орто-) и не 
сосуществуют с $\mathrm{Ca}_{2} \mathrm{~V}_{2} \mathrm{O}_{7}$ и $\mathrm{Ca}_{3}\left(\mathrm{VO}_{4}\right)_{2}$. Из этого следует, что водо- и кислотонерастворимые ванадиевые бронзы всегда сопровождают ванадаты никеля. Их наличие в термообработанном материале требует концентрированных сернокислотных растворов, которые «добирают» ванадий из образовавшихся ванадиевых бронз натрия. Низкая степень извлечения ванадия из никельсодержащих отходов ТЭС обуславливает поиск возможности их использования в металлургии, минуя стадию извлечения ванадия.

\section{Система $\mathrm{V}_{2} \mathrm{O}_{5}-\mathrm{NaVO}_{3}-\mathrm{Mg}_{2} \mathrm{~V}_{2} \mathrm{O}_{7}-\mathrm{Ca}_{2} \mathrm{~V}_{2} \mathrm{O}_{7}$}

Для получения информации, необходимой для тетраэдрации четверной диаграммы системы $\quad \mathrm{V}_{2} \mathrm{O}_{5}-\mathrm{NaVO}_{3}-\mathrm{Mg}_{2} \mathrm{~V}_{2} \mathrm{O}_{7}-\mathrm{Ca}_{2} \mathrm{~V}_{2} \mathrm{O}_{7}$ исследован фазовый состав ряда образцов тройной метаванадатной системы $\mathrm{NaVO}_{3}$ $\mathrm{Ca}\left(\mathrm{VO}_{3}\right)_{2}-\mathrm{Mg}\left(\mathrm{VO}_{3}\right)_{2}$. Обнаружено образование твердого раствора на основе метаванадата кальция с замещением катионной подрешетки на магний и натрий, однако и в этом случае результирующая изоморфная емкость метаванадата кальция не является суперпозицией емкости $\mathrm{Ca}\left(\mathrm{VO}_{3}\right)_{2}$ при замещении ионов кальция на ионы натрия и магния. Результатом этого является нелинейная форма конноды, соединяющей крайние составы твердых растворов на основе метаванадата кальция. Последние вместе с данными о фазовых равновесиях в плоскостях огранения четверной диаграммы дали возможность провести полную тетраэдрацию диаграммы фазовых равновесий системы $\mathrm{V}_{2} \mathrm{O}_{5}-\mathrm{NaVO}_{3}-\mathrm{Ca}_{2} \mathrm{~V}_{2} \mathrm{O}_{7}-\mathrm{Mg}_{2} \mathrm{~V}_{2} \mathrm{O}_{7}$ [5].

Изучение растворимостей соединений, входящих в композиции техногенных отходов ТЭС

В составе термообработанных композиций в зависимости от количества вводимых реагентов могут присутствовать как хорошо, так и труднорастворимые в технологически приемлемых условиях соединения ванадия [7]. Информативными для технологов являются исследования, проведенные в замкнутой системе с измельченным материалом (-0,16 мм) при перемешивании со скоростью 1000 об/мин в изотермическом режиме и заданном показателе $\mathrm{pH}$ среды. Особенностью фазового состава в далеких от равновесия системах с участием оксидов ванадия, натрия, кальция, магния, никеля и марганца совместное присутствие ОВБ и всех образующихся ванадатов возможно при любых соотношениях $\mathrm{Na} / \mathrm{V}$.
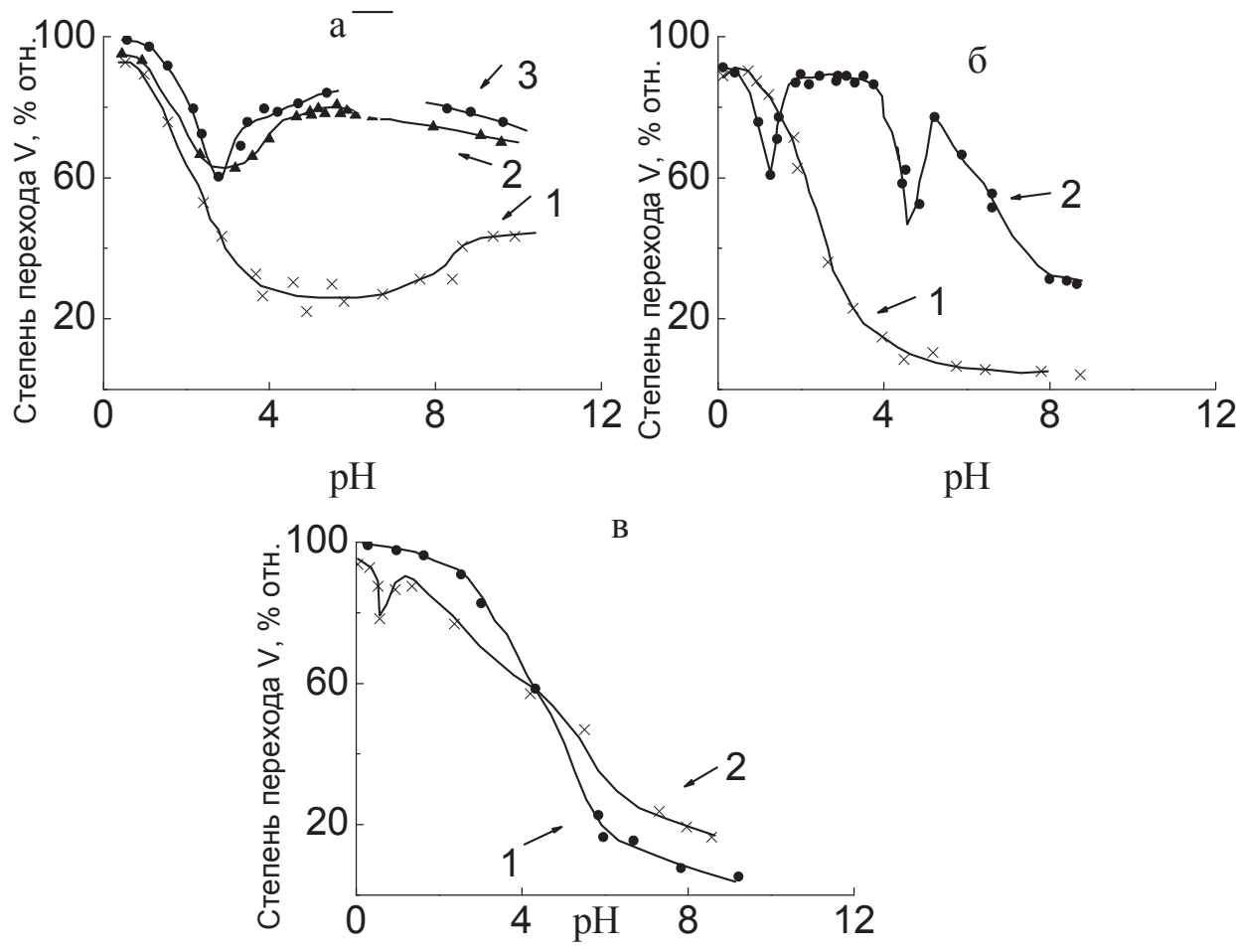

Рисунок 3 - Зависимость степени перехода ванадия в растворы $\mathrm{NaOH}$ и $\mathrm{H}_{2} \mathrm{SO}_{4}$ от величины $\mathrm{pH}$ : $\mathrm{a}-\mathrm{Mg}\left(\mathrm{VO}_{3}\right)_{2} ;$ б $-\mathrm{Mg}_{2} \mathrm{~V}_{2} \mathrm{O}_{7} ; \mathrm{B}-\mathrm{CaMgV}_{2} \mathrm{O}_{7} ; \mathrm{t},{ }^{\circ} \mathrm{C}: 1-20{ }^{\circ} \mathrm{C} ; 2-60{ }^{\circ} \mathrm{C} ; 3-80{ }^{\circ} \mathrm{C}$ 


\section{Система $\mathrm{V}_{2} \mathrm{O}_{5}-\mathrm{Na}_{2} \mathrm{O}-\mathrm{CaO}-\mathrm{MgO}$}

Ванадаты магния наиболее полно реагируют с серной кислотой при $\mathrm{pH}<1$ (рисунок 3 ). При обработке метаванадата магния при различных температурах наибольшая степень извлечения ванадия в раствор достигается при $\mathrm{pH}=0,5-1,0$. Снижение температуры от 80 $60{ }^{\circ} \mathrm{C}$ до комнатной при $\mathrm{pH}=5$ приводит к падению степени перехода ванадия в раствор до $10 \%$. Дальнейшее повышение $\mathrm{pH}$ до 10 позволяет увеличить степень перехода ванадия в раствор до $50 \%$. При $60^{\circ} \mathrm{C}$ минимальная степень перехода ванадия в раствор находится на уровне $72-67,5 \%$ в пределах $\mathrm{pH}=2,0-4,2$. В области $\mathrm{pH}=5-6$ отмечается повышение извлечения ванадия в раствор до $72 \%$. При $80{ }^{\circ} \mathrm{C}$ в области $\mathrm{pH}=2,4-2,6$ степень перехода ванадия в раствор достигает максимума при $\mathrm{pH}$ $=7(87,8 \%)$. Переход в щелочную область отмечен плавным снижением перехода ванадия в раствор при $\mathrm{pH}=11$ до $72 \%$. Пированадат магния в области $\mathrm{pH}=0,5-1,2$ растворяется практически полностью, но с повышением $\mathrm{pH}$ до $6,0\left(20^{\circ} \mathrm{C}\right)$ его растворимость резко падает до $4 \%$ и остается неизменной при переходе в щелочную область. С ростом температуры до $60^{\circ} \mathrm{C}$ характер взаимодействия изменяется: наблюдается резкое падение степени перехода ванадия в раствор до $56 \%$ при $\mathrm{pH}=2$, а затем в области $\mathrm{pH}=2,1-4,4$ происходит повышение до $83-97,8 \%$. В области $\mathrm{pH}=4,1-5,2$ наблюдается второй минимум с переходом ванадия в раствор 46,5\%. Затем степень извлечения ванадия в раствор повышается до $82 \%$ с последующим плавным снижением до 23,5 \% при переходе в щелочную область.

Особенностью четырехкомпонентной диаграммы $\mathrm{V}_{2} \mathrm{O}_{5}-\mathrm{Na}_{2} \mathrm{O}-\mathrm{CaO}-\mathrm{MgO}$ является возможность сосуществования ОВБ натрия с $\mathrm{Mg}\left(\mathrm{VO}_{3}\right)_{2}, \mathrm{Mg}_{2} \mathrm{~V}_{2} \mathrm{O}_{7}$ и $\mathrm{Ca}\left(\mathrm{VO}_{3}\right)_{2}$. Это означает, что даже при значительном содержании ионов натрия, соответствующего образованию водорастворимого $\mathrm{NaVO}_{3}$, присутствие магния ведет к образованию труднорастворимых ОВБ натрия, которые ни при каких условиях (при сохранении заданного соотношения $\mathrm{Na} / \mathrm{V}$ ) не трансформируются в ванадаты натрия. В частности, в рассмотренной области равновесной системы $\mathrm{Na}_{2} \mathrm{O}-\mathrm{CaO}-\mathrm{MgO}-\mathrm{V}_{2} \mathrm{O}_{5}$ ОВБ натрия присутствуют в восьми из тринадцати элементарных систем.

\section{Система $\mathrm{V}_{2} \mathrm{O}_{5}-\mathrm{Na}_{2} \mathrm{O}-\mathrm{CaO}-\mathrm{NiO}$}

Образующиеся в системе $\mathrm{V}_{2} \mathrm{O}_{5}-\mathrm{Na}_{2} \mathrm{O}-\mathrm{CaO}$ $\mathrm{NiO}$ оксидные ванадиевые бронзы натрия находятся в термодинамическом равновесии со всеми ванадатами никеля (мета-, пиро- и орто-) и не сосуществуют с $\mathrm{Ca}_{2} \mathrm{~V}_{2} \mathrm{O}_{7}$ и $\mathrm{Ca}_{3}\left(\mathrm{VO}_{4}\right)_{2}$. Из этого следует, что водо- и кислотонерастворимые ванадиевые бронзы всегда сопровождают ванадаты никеля. Их наличие в термообработанном материале требует концентрированных сернокислотных растворов, которые «добирают» ванадий из образовавшихся ванадиевых бронз натрия.

Зависимость взаимодействия ванадатов никеля с растворами серной кислоты и едкого натра от $\mathrm{pH}$ также свидетельствует о низкой до $10 \%$ степени перехода ванадия в раствор. Увеличение растворимости ванадатов никеля от 10 до $20 \%$ можно достичь только при существенном, до 4 часов, увеличении продолжительности обработки растворами $7 \% \mathrm{H}_{2} \mathrm{SO}_{4}$ (рисунок 4).

Низкая степень извлечения ванадия из никельсодержащих отходов ТЭС обусловила поиск возможности их использования в металлургии, минуя стадию извлечения ванадия с последующим получением $\mathrm{V}_{2} \mathrm{O}_{5}$ и феррованадия. Одним из направлений использования ванадиевого шлама явилось получение на его основе оксидного ванадиевого сплава. Исследования и практическое использование оксидного сплава показали, что при легировании стали он может быть с успехом применен вместо феррованадия [3] .

\section{Десульфурация отходов ТЭС}

Известно, что при отсутствии соединений никеля практически полное осаждение ванадия происходит при соотношении $\mathrm{Fe} / \mathrm{V}=1,5-2[7$, 8]. Осаждение ванадия при совместном присутствии железа и никеля в литературе не описано. С целью определения оптимальных условий получения комплексного низкосернистого ванадий-никель-железо-углеродсодержащего концентрата из зольных высокоуглеродистых отходов ТЭС проведены эксперименты на модельной системе, содержащей $\mathrm{NaVO}_{3}, \mathrm{NiSO}_{4}, \mathrm{FeSO}_{4}$ и $\mathrm{H}_{2} \mathrm{O}$ с корректировкой показателя $\mathrm{pH}$ раствором $\mathrm{Na}_{2} \mathrm{CO}_{3}$. 


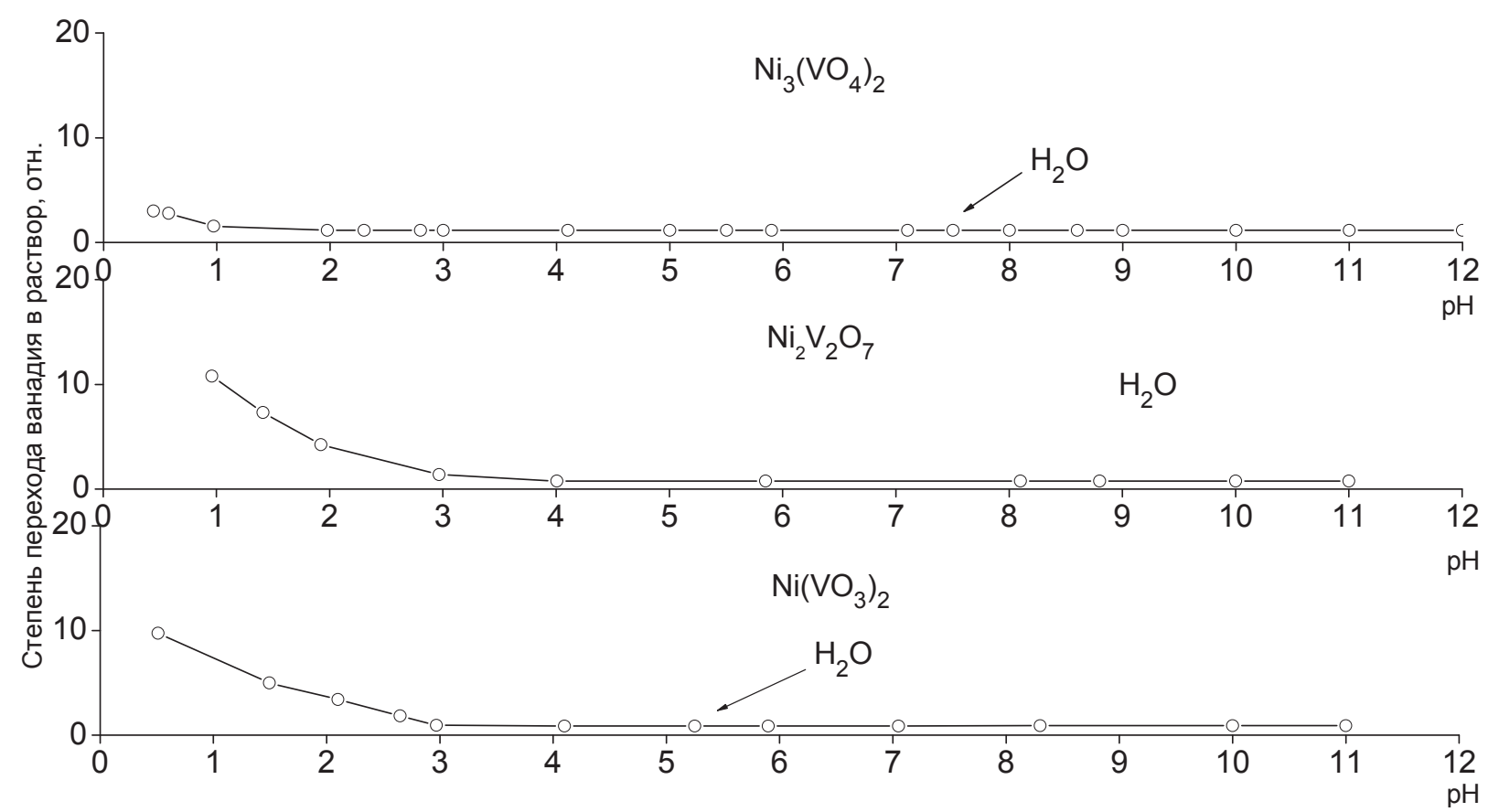

Рисунок 4 - Зависимость степени перехода ванадия в растворы $\mathrm{H}_{2} \mathrm{SO}_{4}$ и $\mathrm{NaOH}$ от величины $\mathrm{pH}\left(\tau=0,5 \mathrm{ч}, \mathrm{t}=60^{\circ} \mathrm{C}\right) . \mathrm{T}: Ж=1: 8$

При получении твердой фазы осаждение проводили при $\mathrm{Fe} / \mathrm{V}=0,50-0,75$ и $\mathrm{Ni} / \mathrm{V}=0,15-$ 1,0 (массовые отношения). Изменение температуры раствора для одного из составов от 20 до $90^{\circ} \mathrm{C}$ показало, что железо и никель практически полностью остаются в осадках, а ванадий осаждается на 99,8 \% только при $20^{\circ} \mathrm{C}$. С повышением температуры до $90^{\circ} \mathrm{C}$ степень его осаждения снижается до 58-60\%. Изменение продолжительности перемешивания, проводимого при $20^{\circ} \mathrm{C}$, выявило, что полнота осаждения ванадия максимальна при перемешивании в течение 1 часа, увеличение экспозиции до 4 часов приводит к снижению степени осаждения до 75 \%. Степень осаждения никеля и железа на уровне 98-100 \% получена независимо от продолжительности перемешивания, при этом содержание серы в осадке изменяется от 0,08 до 0,14 мас. \%. Дальнейшие исследования проводили при $20^{\circ} \mathrm{C}$ и продолжительности перемешивания 1 час. Изменение отношений $\mathrm{Fe} / \mathrm{V}$ и $\mathrm{V} / \mathrm{Ni}$ в системе (таблица 2) позволило выявить их оптимальные пределы, составляющие $0,5-0,75$ и $0,33-0,15$ соответственно.
Следует отметить, что щелочные растворы, полученные после фильтрации при оптимальных условия осаждения, содержат незначительные количества ванадия, никеля и железа (до 0,2 г/л $\mathrm{V}_{2} \mathrm{O}_{5} ; 0,002$ г/л $\mathrm{Ni} ; 0,03$ г/л $\left.\mathrm{Fe}\right)$ и при переработке зол ТЭС могут быть использованы повторно в качестве оборотных растворов. Однако из-за перехода сульфат-ионов в раствор возрастает концентрация сульфата натрия в оборотном растворе. Для выявления влияния концентрации $\mathrm{Na}_{2} \mathrm{SO}_{4}$ на состав твердой фазы проведена серия опытов с добавкой его в исходный раствор от 10 до 250 г/л. Опыты показали, что при изменении отношении $\mathrm{V} / \mathrm{Ni}$ от 0,5 до 6,5 увеличение концентрации сернокислого натрия в исходном растворе до 250 г/л не влияет на степень осаждения ванадия, никеля и железа - она находится на уровне 99,3-99,7\%. Однако при достижении максимальной концентрации сернокислого натрия в исходном растворе содержание серы в осадке возрастает до 3,89 мас. \%, что указывает на нецелесообразность дальнейшего использования оборотного раствора без выведения сульфата натрия. 
Таблица 2 - Зависимость степени осаждения и состава осадков от отношений V/Ni и Fe/V в исходных растворах. Условия опытов: $\mathrm{t}-20^{\circ} \mathrm{C}, \tau-1$ ч; $\mathrm{pH}_{\text {конечное }}=8,5$

\begin{tabular}{|c|c|c|c|c|c|c|c|}
\hline \multicolumn{2}{|c|}{ Отношение } & \multicolumn{2}{|c|}{ Степень осаждения. \% отн. } & \multicolumn{3}{c|}{ Состав осадка, мас. \% } \\
\hline $\mathrm{V} / \mathrm{Ni}$ & $\mathrm{Fe} / \mathrm{V}$ & $\mathrm{V}$ & $\mathrm{Ni}$ & $\mathrm{Fe}$ & $\mathrm{V}$ & $\mathrm{Ni}$ & $\mathrm{Fe}$ \\
\hline 1,0 & 0,50 & 98,0 & 99,9 & 99,8 & 18,9 & 19,2 & 9,6 \\
\hline 1,5 & 0,50 & 95,3 & 99,7 & 99,8 & 21,4 & 15,0 & 11,2 \\
\hline \multirow{4}{*}{3,0} & 0,15 & 31,1 & 96,0 & 92,2 & 18,8 & 19,3 & 8,4 \\
\cline { 2 - 8 } & 0,25 & 41,6 & 97,4 & 96,2 & 21,2 & 16,5 & 12,2 \\
\cline { 2 - 8 } & 0,50 & 88,8 & 99,7 & 99,7 & 24,7 & 9,2 & 13,8 \\
\cline { 2 - 8 } & 0,75 & 94,2 & 95,0 & 99,4 & 21,9 & 7,4 & 17,3 \\
\hline \multirow{4}{*}{4,5} & 0,25 & 39,1 & 83,7 & 93,4 & 17,7 & 12,2 & 15,3 \\
\cline { 2 - 8 } & 0,50 & 85,4 & 98,8 & 98,4 & 25,6 & 6,6 & 14,8 \\
\cline { 2 - 8 } & 0,70 & 97,7 & 99,8 & 99,8 & 24,0 & 5,4 & 17,2 \\
\cline { 2 - 8 } & 0,75 & 98,0 & 99,7 & 99,8 & 24,1 & 5,4 & 18,4 \\
\hline \multirow{3}{*}{6,5} & 0,25 & 37,3 & 75,6 & 80,8 & 26,4 & 8,2 & 14,3 \\
\cline { 2 - 8 } & 0,50 & 76,2 & 96,7 & 99,0 & 26,2 & 5,1 & 17,0 \\
\cline { 2 - 7 } & 0,75 & 91,9 & 99,3 & 99,1 & 24,1 & 4,0 & 19,5 \\
\hline
\end{tabular}

При степени десульфурации исходного сырья на 82-98,4 \% выход ванадия, никеля и железа с твердой фазой составил 95-99; 9899,5; 98,3-99,7 отн. \% соответственно. Остаток от золы после ее водной обработки помимо ванадия, никеля и железа содержал значительное количество углерода. Полученные комплексные ванадий-никель-железо-углеродные концентраты могут быть использованы для выплавки ванадий-никелевой лигатуры, a содержащийся в них углерод служит восстановителем [8].

Одним из вариантов переработки высокосернистых бедных шламов ТЭС (таблица 1), содержащих $\mathrm{CaSO}_{4} \cdot 2 \mathrm{H}_{2} \mathrm{O}$, для последующего использования в производстве легированных сталей является проведение десульфурации обработка раствором карбоната натрия. При этом гипс - фаза, в которую входит сера, взаимодействует c карбонатом натрия по реакции обмена (2), а сера переходит в раствор:

$\mathrm{CaSO}_{4}(\mathrm{~T})+\mathrm{Na}_{2} \mathrm{CO}_{3}(\mathrm{p})=\mathrm{CaCO}_{3}(\mathrm{~T})+\mathrm{Na}_{2} \mathrm{SO}_{4}(\mathrm{p})$

Исследование последовательности фазообразования и характера взаимодействия сульфата кальция с растворами карбоната натрия проводили на модельной системе $\mathrm{CaSO}_{4} \cdot 2 \mathrm{H}_{2} \mathrm{O}$ $\mathrm{Na}_{2} \mathrm{CO}_{3}-\mathrm{H}_{2} \mathrm{O}$. При изучении фазового анализа осадков, полученных при различном соотношении исходных компонентов (m) выявлено, что при перемешивании в течение 30-360 минут при $\mathrm{pH}=7,5-7,8$ и температуре $40{ }^{\circ} \mathrm{C}$ процесс десульфурации протекает ступенчато с образованием промежуточных фаз - глауберита $\mathrm{CaNa}_{2}\left(\mathrm{SO}_{4}\right)_{2}$ и кальций-натриевого карбоната $\mathrm{CaNa}_{2}\left(\mathrm{CO}_{3}\right)_{2}$ :

$$
\begin{aligned}
& 2 \mathrm{CaSO}_{4}+\mathrm{Na}_{2} \mathrm{CO}_{3}=\mathrm{CaNa}_{2}\left(\mathrm{SO}_{4}\right)_{2}+\mathrm{CaCO}_{3} \\
& \mathrm{CaSO}_{4}+4 \mathrm{Na}_{2} \mathrm{CO}_{3}+\mathrm{CaNa}_{2}\left(\mathrm{SO}_{4}\right)_{2}= \\
& =2 \mathrm{CaNa}_{2}\left(\mathrm{CO}_{3}\right)_{2}+3 \mathrm{Na}_{2} \mathrm{SO}_{4} \\
& \mathrm{CaSO}_{4}+\mathrm{CaNa}_{2}\left(\mathrm{CO}_{3}\right)_{2}=2 \mathrm{CaCO}_{3}+\mathrm{Na}_{2} \mathrm{SO}_{4}
\end{aligned}
$$

Реакция (2) протекает полностью с образованием одной твердой фазы - карбоната кальция при $\mathrm{m}=1,0-1,25$ уже через 30 минут перемешивания.

Соединения ванадия хорошо растворимы в растворах карбоната натрия. С целью изучения влияния содержания гипса на концентрацию ванадия в растворах проведена серия опытов с добавлением различного количества метаванадата натрия к раствору карбоната натрия в оптимальных для десульфурации гипса условиях. С увеличением концентрации сульфата натрия с 40,4 до 202,3 г/л в растворе остается до $97,0 \%$ ванадия, так как происходит уменьшение относительной массы ванадатов 
кальция за счет повышения солевого фона в системе и создаются лучшие условия для процесса десульфурации гипса. Степень десульфурации при этом достигает 93,7-99,9\%. Таким образом, на модельных системах показана высокая скорость и полнота растворения гипса при его взаимодействии с растворами карбоната натрия, возможность многократного использования растворов при малой степени потерь ванадия из раствора.

\section{Аттестация шламов ХВО}

Химический анализ твердой фазы шламов ХВО Ново-Стерлитамакской ТЭС (базового материала), а также шламов ряда других ТЭС России (таблица 3) показывает, что состав шламов XBO всех предприятий идентичен. Некоторое варьирование содержания оксидов кальция, кремния и магния объясняется различным составом исходной воды, а также технологическими режимами отчистки воды, выдерживаемыми на каждой ТЭС. Просушенный при $25^{\circ} \mathrm{C}$ шлам XВО представлен $\mathrm{CaCO}_{3}$, после обжига при $1000^{\circ} \mathrm{C}$, в течение 1 часа изменяет состав с образованием $\mathrm{CaO}$ и $\mathrm{Ca}_{2} \mathrm{Fe}_{2} \mathrm{O}_{5}(5$ мол. \%).

\section{XBO \\ Возможные пути использования шламов}

1. Нейтрализация кислых сточных вод и отходов (металлургических, шахтных и подотвальных вод рудных месторождений, химических, бытовых и т.д.) с последующим извлечением из них ценных компонентов.

2. Использование в качестве наполнителя шихты при производстве стройматериалов (стеновых камней) в сочетании с песчаногравийной смесью. Обожженные шламы XВО, согласно проведенным исследованиям, пригодны как высокоэффективные пластифицирующие добавки для строительных и штукатурных растворов

3. В сельском хозяйстве шлам ХВО в гранулированном виде, возможно использовать как. нейтрализующий материал для обработки кислых почв взамен доломитовой муки

4. Использование шламов XВО (вместо применяемого в настоящее время известняка) в качестве кальцийсодержащей добавки при пирометаллургическом извлечении ванадия из ванадийсодержащих отходов электростанций зольных отложений и шламов, образующихся при сжигании мазутов на ТЭС.

В целях исследования комплексного использования двух видов отходов ТЭС поставлен модельный эксперимент [9-12] по извлечению ванадия из термообработанной смеси «среднестатистическая зола ТЭС (табл.1) + шлам XBO» (обжиг при $850{ }^{\circ} \mathrm{C}$ в течение 1 ч) в сернокислый раствор $(\mathrm{pH}=2,6-4,2$, температура $20{ }^{\circ} \mathrm{C}$, продолжительность выщелачивания 30 мин). Используемая зола содержала (в пересчете на оксиды), \% мас.: $\mathrm{V}_{2} \mathrm{O}_{5}-6,5$; $\mathrm{CaO}-2,5 ; \mathrm{Na}_{2} \mathrm{O}-1$; состав шлама XBO приведен выше. В указанном режиме степень извлечения ванадия при молярном соотношении $\mathrm{CaO} / \mathrm{V}_{2} \mathrm{O}_{5}$ $=2,5$ составила $82 \%$ (рисунок 5, кривая 1). Повторная обработка обожженного образца более концентрированной кислотой $(\mathrm{pH}=0,5)$ позволила повысить общее извлечение до 93 \% (рисунок 5, точка 2). Для сравнения на этом же рисунке (рисунок 5, кривая 3) приведена кривая перехода ванадия в раствор серной кислоты из модельной обожженной смеси $\left(0,9 \mathrm{CaCO}_{3}+0,1\right.$ $\mathrm{MgO} / \mathrm{V}_{2} \mathrm{O}_{5}$ ) в тех же методических условиях степень извлечения ванадия в раствор серной кислоты составила $98 \%$. Таким образом, подтверждена принципиальная возможность использования отходов ТЭС - ванадийсодержащих продуктов сгорания мазута и кальцийсодержащих шламов водоочистки, для промышленного извлечения ванадия.

Совместное использование двух отходов ТЭС, ванадийсодержащих зол, шламов и кальцийсодержащих шламов XBO, позволяет получить товарную ванадиевую продукцию: техническую пятиокись ванадия для выплавки феррованадия, твердую фазу после извлечения ванадия, содержащую никель, железо и гипс, являющуюся комплексной шихтой для выплавки ферроникеля, а при отдельной прокалке шлама XВO и обожженную известь, широко используемую в металлургии. Проведенные исследования по разработке физико-химических и технологических основ рационального использования ванадий-никель-железо-кальцийсодержащих отходов теплоэлектростанций позволили предложить принципиальную технологическую схему комплексной переработки зол и шламов тепловых электростанций [1,13-15] для получения товарных продуктов, используемых в металлургии (рисунок 6). Единая технологическая схема предполагает создание научно обоснованной технологии, позволяющей максимально эффективно и экологически безопасно получить забалансовый источник ценных металлов, ванадия и никеля, и оптимизировать качество окружающей среды в промзонах ТЭС с возможностью ликвидации зольных отвалов и шламонакопителей. 
Таблица 3 - Характеристика шламов ХВО различных ТЭС

\begin{tabular}{|c|c|c|c|c|c|c|c|c|c|c|}
\hline \multirow[b]{2}{*}{$\begin{array}{c}\text { Характеристика } \\
\text { шлама XВО }\end{array}$} & \multicolumn{10}{|c|}{ Суспензия шлама XВО } \\
\hline & $\begin{array}{l}\text { Содержа- } \\
\text { ние } \\
\text { твердого, } \\
\text { г/л }\end{array}$ & $\mathrm{pH}$ & $\mathrm{CaO}$ & $\begin{array}{l}\mathrm{C} \\
\text { общ }\end{array}$ & $\begin{array}{l}\mathrm{Fe} \\
\text { об̆щ }\end{array}$ & $\mathrm{MgO}$ & $\mathrm{SiO}_{2}$ & $\mathrm{~S}_{\text {общ }}$ & $\mathrm{P}$ & ППП* \\
\hline $\begin{array}{l}\text { Ново- } \\
\text { Стерлитамакская } \\
\text { ТЭЦ (из шламона } \\
\text { копителя) }\end{array}$ & 17,8 & 11,6 & 50,6 & 11,0 & 1,03 & 4,57 & 2,45 & 0,05 & 0,044 & 42,2 \\
\hline $\begin{array}{l}\text { Ново- } \\
\text { Стерлитамакская } \\
\text { ТЭЦ (текущая } \\
\text { выработка) } \\
\end{array}$ & 16,7 & 11,8 & 51,8 & 11,4 & 0,95 & 3,38 & 2,56 & 0,07 & 0,038 & 41,5 \\
\hline $\begin{array}{l}\text { Кармановская } \\
\text { ГРЭС (из } \\
\text { шламонакопителя) }\end{array}$ & - & - & 45,7 & 13,8 & 8,20 & 2,00 & 3,92 & 0,74 & 0,063 & 39,9 \\
\hline $\begin{array}{l}\text { ТЭЦ-26, г. Москва } \\
\text { (текущая } \\
\text { выработка) }\end{array}$ & - & - & 47,7 & 11,7 & 0,60 & 3,38 & 2,66 & 0,08 & 0,050 & 35,8 \\
\hline & поте & 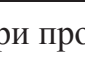 & ва & бр & & 050 & & 1 & & \\
\hline
\end{tabular}

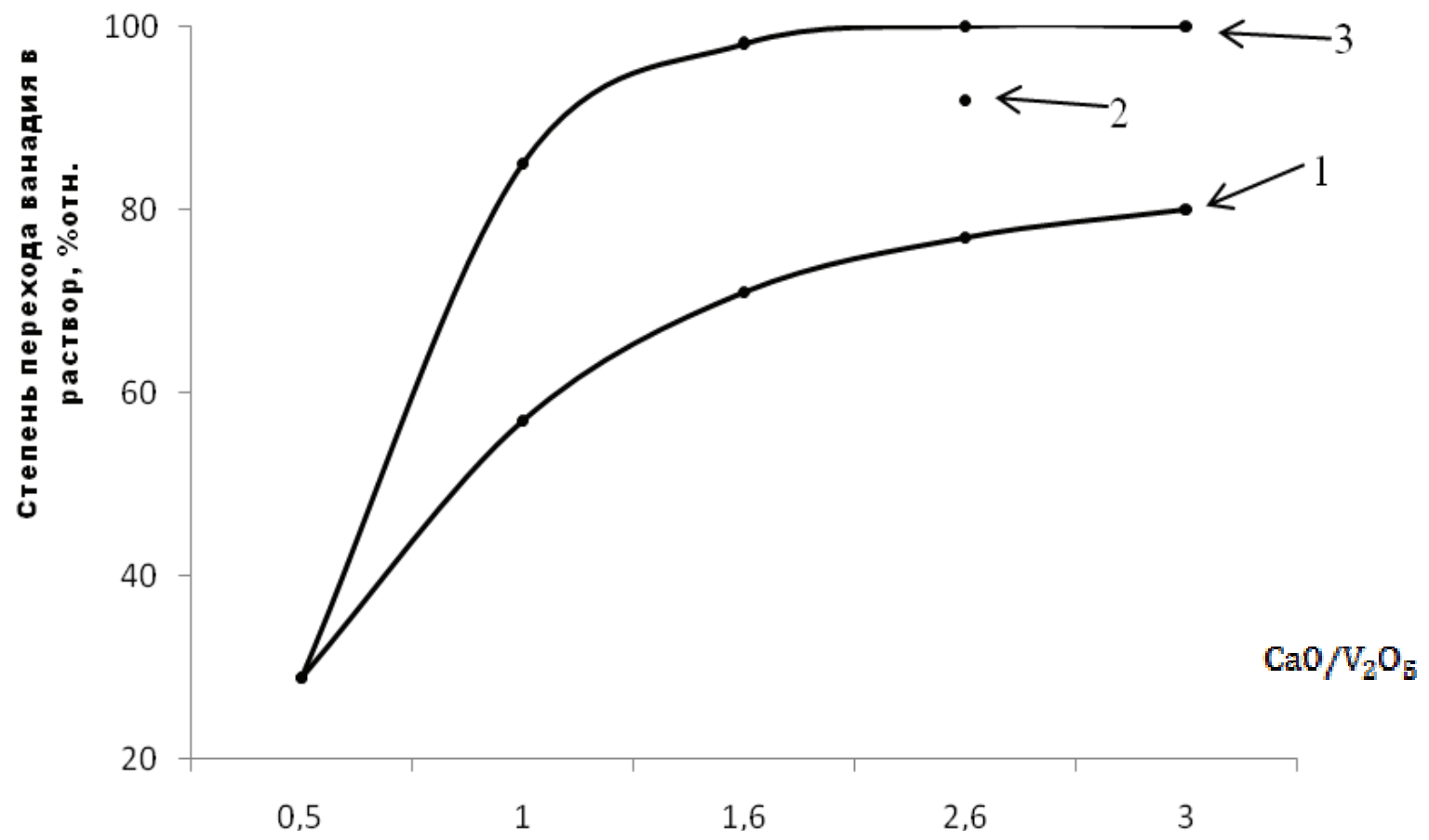

Рисунок 5 - Зависимость степени извлечения ванадия из смеси «ванадийсодержащие отходы + шлам ХВО» (кривая 1,точка 2) и из модельной смеси $\left(0,9 \mathrm{CaCO}_{3}+0,1 \mathrm{MgO}\right) / \mathrm{V}_{2} \mathrm{O}_{5}$ (кривая 3) от соотношения $\mathrm{CaO} / \mathrm{V}_{2} \mathrm{O}_{5}$ 


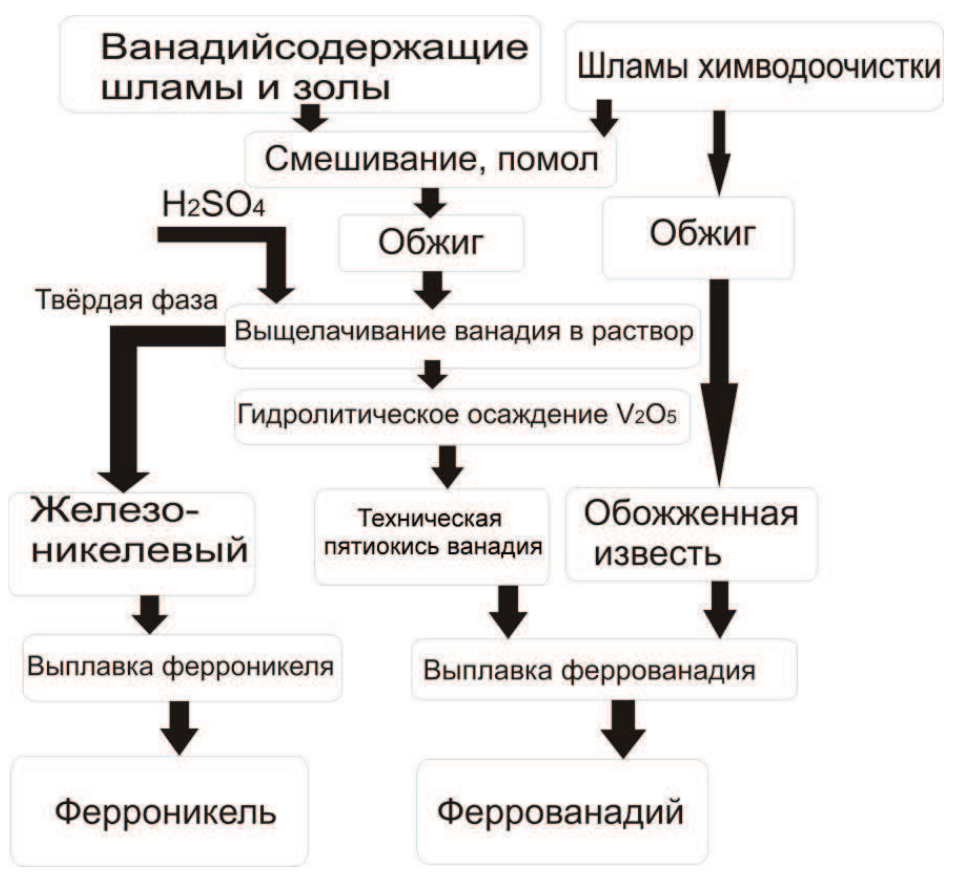

Рисунок 6 - Принципиальная технологическая схема комплексной переработки зол и шламов тепловых электростанций

\section{Заключение}

Установлен элементный и фазовый состав двух видов отходов теплоэлектростанций, сжигающих мазут: ванадий- и никельсодержащих зол и шламов и кальцийсодержащих шламов химической водоочистки. Построены многокомпонентные диаграммы фазовых соотношений в системах $\mathrm{V}_{2} \mathrm{O}_{5}-\mathrm{NiO}(\mathrm{MgO})-$ $\mathrm{CaO}-\mathrm{Na}_{2} \mathrm{O}$, моделирующих состав энергети- ческих отходов. Определена растворимость в кислых и щелочных растворах фаз, образующихся при окислительном обжиге. На модельных системах определены области с максимальным выходом ванадия в раствор. Разработана принципиальная технологическая схема комплексной переработки всех видов отходов с получением товарной ванадий- и никельсодержащей продукции $(\mathrm{FeV}, \mathrm{FeNi})$ и извести.

\section{Литература}

1 Извлечение ванадия и никеля из отходов теплоэлектростанций / под ред.: Т.П. Сирина, В.Г. Мизин, Е.М. Рабинович и др. - Екатеринбург: УрО РАН, 2001. - 338 с.

2 Слободин Б.В., Красненко Т.И., Добрынин Б.Е. и др. Отходы теплоэлектростанций - промышленное сырье для извлечения ванадия. // Металлург. - 2001. - №8. - С. 32 - 35.

3 Комплексная переработка ванадиевого сырья: химия и технология. /под ред.: В.Г. Мизин, Е.М. Рабинович, Т.П. Сирина и др. - Екатеринбург: УрО РАН, 2005. - 415 с.

4 Слободин Б.В., Красненко Т.И., Горбунова Е.М. и др. Регулирование пирометаллургических процессов при извлечении ванадия из промышленного сырья на основе химического моделирования оксидных ванадийсодержащих систем // Металлург. - 2004.- № 2.- С. $44-48$.

5 Слободин Б.В., Красненко Т.И., Добрынин Б.Е. и др. Оксидные ванадиевые бронзы в системах $\mathrm{Na}_{2} \mathrm{O}-\mathrm{CaO}-\mathrm{MO}-$ $\mathrm{V}_{2} \mathrm{O}_{5}(\mathrm{M}=\mathrm{Mg}, \mathrm{Ni}) / /$ Журнал неорган. химии. - 2001. - Т. 46, № 11. - С. $1922-1926$.

6 Слободин Б.В. Химическое моделирование образования ОВБ натрия и ванадатов при извлечении ванадия из многокомпонентного сырья // XIII Всероссийское совещание по высокотемпературной химии силикатов и оксидов (Санкт-Петербург, 19 - 21 ноября 2002 г.): тез. докл. - СПб.: Институт химии силикатов им. И.В. Гребенщикова РАН, 2002. - C. 62.

7 Сирина Т.П., Фотиев А.А., Красненко Т.И. Изучение взаимодействия $\mathrm{Mg}\left(\mathrm{VO}_{3}\right)_{2}, \mathrm{Mg}_{2} \mathrm{~V}_{2} \mathrm{O}_{7}, \mathrm{CaMgV}_{2} \mathrm{O}_{7}$ с растворами серной кислоты и гидроксида натрия // VI Всесоюзное совещание по химии, технологии и применению ванадиевых соединений (Нижний Тагил, 16 - 18 мая 1990 г.): тез. докл. - Нижний Тагил, 1990. - С. 150 - 153.

8 Сирин А.В., Красненко Т.И., Сирина Т.П. и др. Десульфурация зол мазутных тепловых электростанций с 
получением комплексных ванадий - никелевых концентратов // Международный симпозиум «Порядок, беспорядок и свойства оксидов ODPO-2006» (Сочи, 19 - 23 сентября 2006 г.): сб. тр. - Ростов-на-Дону: изд-во Ростовского государственного университета, 2006. - С. $119-121$.

9 Сирин А.В., Красненко Т.И., Мизин В.Г. и др. Десульфурация вторичного ванадиевого сырья // Металлург. 2006. - № 11. - С. 43 - 46.

10 Красненко, Т.И. Диаграммы фазовых равновесий - основа реализации технологий переработки техногенных отходов // Известия Российской Академии Наук. Серия физическая. - 2010. - Т. 74, № 8. - С. 1217 - 1220.

11 Красненко, Т.И. Ресурсоэкологический подход к проблеме переработки техногенных отходов мазутных теплоэлектростанций России // Всероссийская конференция «Исследования в области переработки и утилизации техногенных образований и отходов» (Екатеринбург, 24-27 ноября 2009): тр. Всерос. конф. с элементами школы для молодых ученых.-Екатеринбург, 2009. - С. 94 - 96.

12 Красненко Т.И., В.Г.Бамбуров. Физико - химическая модель оптимизации качества окружающей среды в промышленной зоне теплоэлектростанций // Журнал «Химическая технология». - 2010. - Т.11, №6. - С . 380 - 383.

13 Красненко Т.И., В.Г.Бамбуров. Физико-химические основы комплексной переработки ванадийсодержащих отходов // IX Международное Курнаковское совещание по физико-химическому анализу: тез. докл.- Пермь, 2010. C. 281.

14 Красненко, Т.И. Комплексная переработка ванадийсодержащих отходов ТЭС Урала и Сибири // Симпозиум "Уральская горная школа - регионам" (Екатеринбург, 11 - 12 апреля 2011 г.): сб. докл. - Екатеринбург, 2011. - С. 159 -160 .

15 Бамбуров В.Г., Ленев Д.С., Сирина Т.П. и др. Извлечение ванадия и молибдена из концентратов и техногенных отходов // 14-й Международный симпозиум «Порядок, беспорядок и свойства оксидов ОДРО-14» (п. Лоо, 14 -19 сентября 2011 г.): сб. тр. - Ростов-на-Дону: изд-во СКНЦ ВШ ЮФУ АПСН, 2011.- Т. 1. - С. 192 - 194.

\section{References}

1 Sirina T.P., Mizin V.G., Rabinovich E.M. Extraction of vanadium and nickel from waste thermal power plants [Izvlechenie vanadiya I nikelya iz othodov teploelectrostanciy]. Ekaterinburg: UrO RAN, 2001. 338 p .

2 Slobodin B.V., Krasnenko T.I., Dobrynin B.E. Wastes from thermal power plants - industrial raw materials for the extraction of vanadium [Othodi teploelectrostanciy - promishlennoe sir'e dlya izvlecheniya vanadiya]. Metallurg Metallurgist, 2001. 8. P. 32-35.

3 Complex processing of vanadium raw materials: chemistry and technology [Kompleksnaya pererabotka vanadievogo sir'ya: himiya i tehnologia]. Edited by Mizin V.G., Rabinovich E.M., Sirina T.P. Ekaterinburg: UrO RAN, 2005. $-415 \mathrm{p}$.

4 Slobodin B.V., Krasnenko T.I., Gorbunova E.M. Regulation of pyrometallurgical processes for extracting vanadium from industrial raw materials on the basis of chemical modeling of vanadium oxide systems [Regulirovanie pirometallurgicheskih processov pri izvlechenii vanadiya iz promishlennogo sir'ya na osnove himicheskogo modelirovaniya oksidnih vanadiyisoderzhashih system]. Metallurg - Metallurgist, 2004. 2. P. 44-48.

5 Slobodin B.V., Krasnenko T.I., Dobrinin B.E. Vanadium oxide bronze in system Na2O-CaO-MGO-V2O5 (M = $\mathrm{Mg}, \mathrm{Ni})$ [Oksidnie vanadiyevie bronzi v sistemah $\mathrm{Na}_{2} \mathrm{O}-\mathrm{CaO}-\mathrm{MO}-\mathrm{V}_{2} \mathrm{O}_{5}(\mathrm{M}=\mathrm{Mg}$, Ni)]. Jurnal neorgan. himii. - Russian Journal of inorg.chem., 2001. 46, 11. P. $1922-1926$.

6 Slobodin B.V. Chemical modeling formation of EOD sodium vanadate and the extraction of vanadium from a multicomponent material [Himicheskoe modelirovanie obrazovania OVB natria $i$ vanadatov pri izvlechenii vanadiya iz mnogokomponentnogo sirya]. XIII Vserossiskoe soveshanie po visokotemperaturnoi himii silikatov i oksidov (SanktPeterburg, 19 - 21 november 2002.): tez. dokl.- Sankt-Peterburg: Institut himii silikatov im. I.V. Grebenshikova RAN, 2002. P. 62.

7 Sirina, T.P. Studying the interaction of $\mathrm{Mg}\left(\mathrm{VO}_{3}\right)_{2}, \mathrm{Mg}_{2} \mathrm{~V}_{2} \mathrm{O}_{7}, \mathrm{CaMgV}_{2} \mathrm{O}_{7}$ with solutions of sulfuric acid and sodium hydroxide [Izuchenie vzaimodeistvya $\mathrm{Mg}\left(\mathrm{VO}_{3}\right)_{2}, \mathrm{Mg}_{2} \mathrm{~V}_{2} \mathrm{O}_{7}, \mathrm{CaMgV}_{2} \mathrm{O}_{7}$ s rastvorami sernoi kisloti $i$ gidroksida natriya] . VI Vsesoiyznoe soveshanie po himii, technologii i primeneniiy vanadiyevih soedinenii (Nijnii Tagil, 16 - 18 may 1990 г.): tez. dokl. Nijnii Tagil , 1990. P. $150-153$.

8 Sirin A.V., Krasnenko T.I., Sirina T.P. Desulphurization of oil - fired thermal power plant ash to form complex vanadium - nickel concentrates [Desulfuracia zol mazutnih teplovih elektrostancii s polucheniem kompleksnih vanadii nikelevih]. Mejdunarodni simpozium «Poriydok, besporiydok i svoistva oksidov ODPO-2006» (Sochi, 19 - 23 september 2006 g.): sb. tr. - Rostov-on-Don: Publishing House of the Rostov State University Press, 2006. P. 119 - 121.

9 Sirin A.V., Krasnenko T.I., Mizin V.G. Desulphurization of secondary raw vanadium [ Desul'furaciya vtorichnogo vanadievogo sir'ya] . Metallurg - Metallurgist, 2006. 11 .P. 43-46.

10 Krasnenko T.I. The equilibrium phase diagram - the basis of the industrial waste recycling technology [Diagrammi fazovih ravnovessiiy - osnova realizacii tehnologii pererabotki tehnogennih othodov] Izvestiya Rossiiyskoy Akademii Nauk. Seriya fizicheskaya - Bulletin of the Russian Academy of Sciences: Physics, 2010. 74, 8. P. 1217 - 1220.

11 Krasnenko T.I. Environmental resource approach to the processing of industrial waste of oil-fired power plants of Russia [Resursoecologicheskiyi podhod $k$ problem pererabotki tehnogennih othodov mazutnih teploelektrostanciiy Rossii]. All-Russian Conference "Research in the field of processing and recycling of waste and man-made structures" (Ekaterinburg, 24-27 november 2009): tr. All-Russia. Conf. with elements of a school for young scientists. Ekaterinburg, 2009. PP. 94 - 96.

12 Krasnenko T.I. Physical - chemical model to optimize the quality of the environment in the industrial area of thermal 
power plants [ Fiziko-himicheskaya model' optimizacii kachestva okruzhaushei sredi v promishlennoy zone teploelectrostanciyi]/ Krasnenko T.I., Bamburov V.G. // Zhurnal «Himicheskaya tehnologiya» - "Chemical Technology" magazine . - 2010. - T.11, №6. - PP. $380-383$.

13 Krasnenko T.I. Physico-chemical basis of complex processing of vanadium waste [ Fiziko-himicheskie osnovi kompleksnoy pererabotki vanadiysoderzhashih othodov] Kurnakovskoe IX International Meeting on the physical and chemical analysis: Theses. Reports. [IX Mezhdunarodnoe Kurnakovskoe soveshanie po fiziko-himicheskomu analizu: tez. dokl]. Per'm, 2010. P. 281.

14 Krasnenko T.I. Complex processing of vanadium-containing waste CHP Urals and Siberia [Kompleksnaya pererabotka vanadiysoderzhashih othodov TEC Urala I Sibiri]. Symposium "Ural Mining School - Region" [Simpozium «Ural'skaya gornaya shkola - regionam»] (Ekaterinburg, 11-12 april 2011 y.): Proceedings. Ekaterinburg, 2011. P. 159 - 160.

15 Bamburov V.G., Lenev D.S., Sirina T.P. Extraction of vanadium and molybdenum concentrates from industrial waste [Izvlechenie vanadiya I molibdena iz koncentratov I tehnogennih othodov]. 14th International Symposium "Order, Disorder and Properties of Oxides ODRO-14" [14-I Mezhdunarodniy simpozium "Poryadok, besporyadok $i$ svoystva oksidov ODRO-14»](p. Loo, 14 -19 september 2011 y.): Proceedings. Rostov-na- Donu SKNC VSH UFU APSN, 2011. T. 1. PP. 192 $-194$.

Работа выполнена в рамках проектов: №12-П-3-1016. Программа фундаментальных исследований Президиума РАН (№27); Министерства образования и науки №63781 2011. 